\title{
EFFECT OF MALTREATMENT ON SELECTED ASPECTS OF INTELLIGENCE AMONG SCHOOL AGE CHILDREN
}

Prof. Amal Ahmed Khalil ${ }^{1}$, Assiss.Prof. Rehab Hanie Elkazaz ${ }^{2}$, Dr. Maha Mahmoud Saadoon ${ }^{3}$, Eman Mohamed El-Daify Abdel-Ghany Ahmed ${ }^{4}$ Professor of Pediatric Nursing ${ }^{1}$; Assist. professor of pediatric nursing ${ }^{2}$; lecturer $^{2}$ of pediatric nursing ${ }^{3}$; Demonstrator of pediatric nursing ${ }^{4}$. Faculty of Nursing Port Said University

\begin{abstract}
Background: Child maltreatment demonstrates effects of all intellectual profile specialty linguistic, social, and emotional intelligence that causes a lower level of school achievement. Aim: This study was aimed to determine the effect of maltreatment on selected aspects of intelligence among school age children. Design: A descriptive correlation research design was utilized to conduct the current study. Setting: Primary schools of Port Said City at six districts. Subjects: Stratified cluster random sampling of 12 primary schools of Port Said City at six districts. 422 students aging nine to twelve years old. Data collection tools: Tool I: structured Interview for socio-demographic data Tool II: A buse and neglect scale and sexual abuse scale. Tool III: linguistic intelligence scale, social intelligence scale, and emotional intelligence scale. Results: Most common maltreatment among the studied students was neglect, $27 \%$, and physical abuse, $24.2 \%$, followed by emotional abuse, $18.5 \%$, and only, $0.2 \%$, were exposed to sexual abuse. The majority of studied students had linguistic and emotional intelligence. Conclusion: There was a negative correlation between child abuse and the selected aspects of intelligence (linguistic, social, and emotional) Recommendations: Conduct a training program for the parents about the seriousness of the abuse and its effects on the level of intelligence.
\end{abstract}

Key Words: Intelligence, Maltreatment, School-Age Children 


\section{INTRODUCTION}

Child maltreatment is considered a major public health problem, associated with serious short-term and long-term negative consequences, such as physical, behavioral, and psychological problems (vanderPut, Assink, Gubbels,\& van Solinge, 2018). Child maltreatment includes physical abuse, emotional abuse, sexual abuse and neglect including physical neglect, emotional neglect, and educational neglect, and witnessing family violence which has recently been added to the catalog of maltreatment types, and suggested to carry possibly serious developmental consequences (Witt, Brown, Plener, Brähler, \&Fegert, 2017).

Intelligence is the intellectual capacity of humans, which is characterized by perception, consciousness, self-awareness, and volition. Intelligence enables humans to remember descriptions of things and use those descriptions in future behaviors. It is a cognitive process. It gives humans the cognitive abilities to learn, form concepts, understand, and reason, including the capacities to recognize patterns, comprehend ideas, problem solve and use language to communicate. Intelligence enables humans to experience and think (Singh, 2017).

Child maltreatment is significantly negatively impacted intellectual ability, which in turn can have a pervasive effect on academic, social, and emotional development. Indeed, intelligence is a powerful predictor of academic performance. which in turn has been found to predict dropout rates, educational attainment, socioeconomic status, and engaging in criminal behavior (Davis, Moss, Nogin, \& Webb, 2015).

\section{Significance of the study:}

More than 1 billion children are being exposed to maltreatment; $23 \%$ have been exposed to physical abuse, $36 \%$ have been exposed to emotional abuse, $16 \%$ have been exposed to physical neglect, and $26 \%$ have been exposed to sexual abuse (18\% of which are girls, and $8 \%$ of which are boys) (World Health Organization,2017). Research in nursing did not give enough consideration to the effect of maltreatment on selected aspects of intelligence among school-age children. The result that will be generated from this study will be useful for nurses and health care professionals for detection of maltreatment problems that might face the children. 


\section{AIM OF THE STUDY:}

Determine the effect of maltreatment on selected aspects of intelligence among school-age children

\section{Research questions:}

1) What is the effect of maltreatment on Linguistic Intelligence?

2) What is the effect of maltreatment on social Intelligence?

3) What is the effect of maltreatment on emotional Intelligence?

\section{SUBJECTS AND METHOD :}

Subjects and methods for this study would be portrayed under four main designs as follow:

I: Technical Design.

II: Operational Design

III: Administrative Design.

IV: Statistical Design.

\section{I: Technical Design:}

The technical design will include the research design, study setting, subjects, and tools of data collection.

\section{Research Design:}

A descriptive correlational research design was utilized to conduct the current study.

\section{Study Setting:}

The present study was carried out at 12 primary schools in Port Said City. Representing the six districts of Port-Said city, namely El-Manakh, El-Arab, El-Dawahy, El-Shark, El-Zohor, and El-Ganon. From each respective area, 2 primary schools were chosen randomly. As the following:- El-Zohor, Bank Portsaid Elwatany, Aly En AbyTalb, El-Manakh, Mustafa Kamel, El-Tanes, El-Arab, Ashtom El-gameel, Kasem Amine, El-Dawahy, El-Yaremok, Bader, El-Shark, Om El-Moemenen, Alfath, and El-Ganob, El-cape, and Bilal ibn Rabah school.

\section{Study Subjects:}

The subject of this study consisted of 221 (52.4\%) boys and 201(47.6\%) girls enrolled in the previous schools and ranged between 9-12 years. 


\section{Sample size calculations:}

Sample size $=\frac{\mathrm{z} 1-\propto / 2^{2} \mathrm{p}(1-\mathrm{p})}{\mathrm{d}^{2}}($ Charan and Biswas, 2013)

Where:

$\mathrm{Z} \alpha=\mathrm{a}$ percentile of standard normal distribution by confidence level=1, 96

$\mathrm{P}=$ Expected proportion in population based on previous studies

(Prevalence of Physical and emotional abuse among school-age children $=48.2 \%$ according to (Saad, Hashish, Abdel-Karim, \& Mohammed, 2016).

D: absolute error or precision $(5 \%)$

$\mathrm{N}=1,96 \times 0,482(1-0,482)=384$

$$
(0,05) 2
$$

Assuming a $10 \%$ attrition rate:

$$
\begin{aligned}
& 10 \% \text { of } 384=38.4 \\
& 384+38.4=422.4=422
\end{aligned}
$$

\section{Sampling technique}

The study was conducted in the 12 school in Port Said city. This was selected by stratified cluster random sampling. Port Said schools were classified into six strata, according to districts; two schools were randomly selected from each to the six strata, for a total sample of twelfth schools. Within the selected schools, classes constituted the clusters. Two clusters were randomly selected from each selected school to fulfill the required sample size. After correction for a dropout rate of about 10\%, the required sample size was 422 school children. This was equally divided among the twelfth schools.

\section{Tools of Data Collection:}

Six tools were used to collect data as follows.

\section{Tool I: Children characteristic}

A structured Interview was developed by the researcher to collect socio-demographic data, which includes 9 questions that measured the Child's age, gender, mother's education and occupation, father's education and occupation...etc.

\section{Tool II: Child Abuse and Neglect Scale.}

It was developed by Abatha, (2005), can exposed child abuse by (father, mother) and composed of three parts as follows. 


\section{Part 1:- Physical Abuse Scale}

It consists of (22) questions, which to measure the frequency of physical abuse, as punching, beating, kicking, biting, burning. Scoring as follow: not present... (0), rare... (1), often... (2) and common... (3), The total score was obtained by summation of the scores of each statement, so it ranged between zero to 66 , a child was more exposed to physical abuse if the total percent score was $60 \%$ or more and child was less exposed to physical abuse if the score less than $60 \%$.

\section{Part 2:- Emotional Abuse Scale}

It consists of (22) questions, which to measure the frequency of emotional abuse, as ridicule, degradation, and routine labeling or humiliation scoring as follow: not present... (0), rare... (1), often... (2) and common... (3), The total score was obtained by summation of the scores of each statement, so it ranged between zero to 66 , a child was more exposed to emotional abuse if the total percent score was $60 \%$ or more and child was less exposed to emotional abuse if the score less than $60 \%$.

\section{Part 3:- Neglect Scale}

It consists of (22) questions, which to measure the frequency of neglect, like the absence of sufficient attention and responsiveness, scoring as follow: not present... (0), rare... (1), often... (2) and common... (3), the total score was obtained by summation of the neglect of the total percent score was $60 \%$ or more and child was less exposed to neglect if the score less than $60 \%$.

\section{Part 4: Sexual Abuse Scale}

It was developed by Mansour, (2008). It was consists of (12) questions, which to measure sexual abuse. As touching or fondling a child, forcible kissing, sexual advances towards a child during travel, Scoring as follow: rare... (1), often... (2) and common... (3). The total score was obtained by summation of the scores of each statement, so it ranged between zero to 36 , a child was more exposed to sexual abuse if the percent score was $60 \%$ or more and the child was less exposed to sexual abuse if less than 60\%. can exposed child abuse by (father, mother, sibling).

\section{Tool III: Aspects of intelligence}

\section{Part 1: Linguistic Intelligence Scale.}

It was developed by Ghanem, (2011). It consists of (13) questions. It is used to measure language ability and fluency in expression in different ways, scoring as follows: not very agree.... (0), not little agree... (1) Little agrees.... (2) Very agree..... (3). The total score is 
obtained by summation of the scores of each statement, so it ranged between zero to 39 , the child was a higher level of linguistic intelligence if the percent score was $60 \%$ or more and the child with the lower level of linguistic intelligence if less than $60 \%$.

\section{Part 2: Social Intelligence Scale:}

It was developed by Al-Qatros, (2008). It consists of (16) questions. It is used to measure emotional sensitivity, socio-emotional control, and social sensitivity. Scoring as follow: rare... (1), often... (2), and common... (3). The total score is obtained by summation of the scores of each statement, so it ranged between zero to 48 , the child was a higher level of social intelligence if the percent score was $60 \%$ or more and the child with a lower level of social intelligence if less than $60 \%$.

\section{Part 3: Emotional Intelligence Scale.}

It was developed by Al-Qatros, (2008). It consists of 16 items. It is used to measure selfawareness, self-motivation, empathy, and handling relationships. Scoring as follow: rare... (1), often... (2), and common... (3). The total score is obtained by summation of the scores of each statement, so it ranged between zero to 48 , the child had a higher level of emotional intelligence if the percent score was $60 \%$ or more and the child with a lower level of emotional intelligence if less than $60 \%$.

\section{II: Operational Design:}

The operational design included the preparatory phase, pilot study, reliability of the tool, and fieldwork.

\section{a. Preparatory phase:}

It includes reviewing of literature, different studies, and theoretical knowledge of various aspects of the problems using books, research articles, internet, periodicals, and Journals

\section{b.Pilot Study:}

A pilot study was undertaken before starting the data collection phase. It was carried out on (10\%) 45 school-age children not included in the study. It was conducted in November 2018. The purpose of the pilot study was to test the applicability and the feasibility of the study tools, and it served to estimate the time needed to complete the tools. It also helped to find out any obstacles and problems that might interfere with data collection.

\section{c. Reliability of Tool:}

Cronbach alpha coefficient was calculated to assess the reliability of tools through their internal consistency by previous authors in the following table. 


\begin{tabular}{|c|c|c|}
\hline Tool Number & Reliability Score & Author \\
\hline $\begin{array}{c}\text { Tool (II) } \\
\text { Child Abuse and } \\
\text { Neglect Scale }\end{array}$ & $\begin{array}{c}\text { Physical abuse } 0.87 \\
\text { Emotional abuse } 0.80 \\
\text { Neglect } 0.82 \\
\text { Total of scale } 0.87\end{array}$ & Abatha, (2005) \\
\hline $\begin{array}{c}\text { Tool (III) } \\
\text { Sexual Abuse Scale }\end{array}$ & $\begin{array}{c}\text { Father } 0.79 \\
\text { Mother 0,64 }\end{array}$ & Mansour, (2008) \\
\hline $\begin{array}{c}\text { Tools(IV) } \\
\text { Linguistic Intelligence } \\
\text { Scale }\end{array}$ & 0.85 & Ghanem, (2011) \\
\hline $\begin{array}{c}\text { Tools(V) } \\
\text { Social Intelligence } \\
\text { Scale }\end{array}$ & $\begin{array}{c}\text { first dimension } 0.73 \\
\text { second dimension } 0.60 \\
\text { third dimension } 0.50 \\
\text { total } 0.72\end{array}$ & Al-Qatros, (2008) \\
\hline $\begin{array}{c}\text { Tools (VI) } \\
\text { Emotional Intelligence } \\
\text { Scale }\end{array}$ & $\begin{array}{c}\text { first dimension } 0.84 \\
\text { second dimension } 0.50 \\
\text { third dimension } 0.50 \\
\text { total } 0.80\end{array}$ & Al-Qatros, (2008) \\
\hline
\end{tabular}

\section{d. Field Work:}

The directors of the school and children's were informed about the purpose of the study, children oral consent was taken, they were informed about their right to refuse participation in the study and that their answers will not be taken against them, it will be used just for the purpose of the study. The study was conducted using the interview technique that was conducted on an individual basis. The researcher started to collect data for two days per week. A number of 10-20 children were interviewed per day. Each interview lasted for 2535 minutes, depending on the response of the interviewee; the process of data collection took a period of six months from start of November 2018 to end of Apri2019.

\section{III: Administrative Design:}

Before starting any step in the study, an official letter was be issued from the Dean of the Faculty of Nursing to the Directorate of education in port said city was informed in requesting for cooperation and permission to conduct the study in schools. 


\section{Ethical consideration}

1- An approval taken from research ethic committee of Faculty of Nursing, Port Said University

2- An approval taken from directors of the schools to participate in the study after explanation the study aim.

3-An approval taken from each participant (children's) after explanation of the study aim and details data collection process to be familiar with the importance of his/her participation

\section{IV: Statistical Design:}

Data entry and statistical analysis were done using SPSS 16.0 statistical software package. Data were presented using descriptive statistics in the form of frequencies and percentages for qualitative variables, and means and standard deviations for quantitative variables. Pearson correlation coefficient analysis was used to test the scales used in the study. Statistical significance was considered at $\mathrm{P}$-value $<0.05$ and $\mathrm{p}<0.001$.

\section{RESULTS:}

Table (1): The student in this study were 422 children, ranged between $9-12$ years old with Mean \pm SD $10.3 \pm 1.05$. About more than half of studied children (52.4\%) were boys. Nearly more than one-third of studied children (36.5\%) are in fifth grade. Also, 33.2\% of the studied students were in second child's ranking..

Table (2): Regarding studied children's parents, father age ranged between 20->50 with mean 39.5 \pm 8.1 years, More than one-quarter of studied father's (30.6\%) had basic education. As regards the occupation, the majority of studied fathers $(98.8 \%)$ were working. On the other hand, the mother's age ranged between 20->50 years old with a mean of 34.1 27.1 years. More than two-fifth of studied mothers $(40.8 \%)$ had basic education, while more than twothirds of the studied mothers $(66.8 \%)$ were not working. Less than two-third of studied parents $(63.0 \%)$ were living together. About the residence of studied parents, the majority of them (98.6\%) living in urban. The majority of family $(92.9 \%)$ reported having enough income.

Figure (1): shows that $15.2 \%$ of studied students had a high level of abuse. While $84.8 \%$ of them had less level of abuse , as specifically for each type of abuse, $27 \%$ of studied students reported neglect as most vulnerable followed by physical abuse as a level of $24.2 \%$ and finally level of emotional abuse as $18.5 \%$. Concerning sexual abuse, only $0.2 \%$ of the most vulnerable and the majority (99.8\%) are least exposed . 
Figure (2): shows that $88.6 \%$ of studied students had high intelligence. While $11.4 \%$ of them had less intelligence .Regarding aspects of intelligence, linguistic intelligence was (93.6\%) high intelligence, on the other hand, 6.4\% of low intelligence. Conversely, social intelligence more than half (55\%) were high intelligence, as well as $45 \%$ were low intelligence. Additionally, emotional intelligence vast majority (81.3) were high intelligence, also $18.7 \%$ were low intelligence.

Table (3): the relation between child characteristics and total physical abuse among studied students, shows that statistically significant relation between age and total physical abuse $(\mathrm{P}=.001)$.

Table (4): the relation between child characteristics and aspects of intelligence among studied students, shows that was found a statistically significant relation between gender and linguistic, social intelligence $(p=.000, .050)$. it was also shown that there was a statistically significant relation between grade and emotional intelligence $(\mathrm{p}=.000)$.

Table (5): correlation between types of child abuse and aspects of intelligence among studied students, as shown there statistically significant negative correlation between neglect and linguistic intelligence $(\mathrm{P}=.002)$. Also, statistically significant negative correlation between neglect and social intelligence $(\mathrm{P}=.000)$.

Table (6): correlation between child total intelligence and total maltreatment among studied students, as shown there statistically significant negative correlation between total child maltreatment and total intelligence among studied students $(\mathrm{p}=.027)$ 
Table 1: Distribution of the studied students according to their socio-demographic characteristics $(n=422)$

\begin{tabular}{|c|c|c|}
\hline $\begin{array}{c}\text { School-age children } \\
\text { characteris tic }\end{array}$ & No & $\%$ \\
\hline Age / years & & \\
\hline $9<10$ & 123 & 29.1 \\
\hline $10<11$ & 129 & 30.6 \\
\hline $11-12$ & 170 & 40.3 \\
\hline Mean \pm SD & \multicolumn{2}{|c|}{$10.3 \pm 1.05$} \\
\hline Gender & & \\
\hline Boys & 221 & 52.4 \\
\hline Girls & 201 & 47.6 \\
\hline \multicolumn{3}{|l|}{ Grade } \\
\hline Fourth & 130 & 30.8 \\
\hline Fifth & 154 & 36.5 \\
\hline Sixth & 138 & 32.7 \\
\hline \multicolumn{3}{|l|}{ Child's Ranking } \\
\hline First & 139 & 32.9 \\
\hline Second & 140 & 33.2 \\
\hline Third & 92 & 21.8 \\
\hline Fourth & 48 & 11.4 \\
\hline fifth & 3 & 0.7 \\
\hline
\end{tabular}


Table 2:Distribution of the socio-demographic characteristics of parents as reported by studied students $(\mathrm{n}=422)$

\begin{tabular}{|c|c|c|}
\hline Parents' characteristics & No & $\%$ \\
\hline \multicolumn{3}{|l|}{ Father Age / vears } \\
\hline $20<30$ & 28 & 6.6 \\
\hline $30<40$ & 206 & 48.8 \\
\hline $40<50$ & 153 & 36.3 \\
\hline$\geq 50$ & 35 & 8.3 \\
\hline Mean \pm SD & \multicolumn{2}{|c|}{$39.5 \pm 8.1$} \\
\hline Father Educational level & & \\
\hline Illiterate & 7 & 1.7 \\
\hline Basic education & 129 & 30.6 \\
\hline Diploma & 110 & 26.1 \\
\hline Institute & 49 & 11.6 \\
\hline University & 127 & 30.1 \\
\hline \multicolumn{3}{|l|}{ Father Occupation } \\
\hline Work & 417 & 98.8 \\
\hline Not work & 5 & 1.2 \\
\hline \multicolumn{3}{|l|}{ Mother Age / years } \\
\hline $20<30$ & 115 & 27.3 \\
\hline $30<40$ & 253 & 60.0 \\
\hline $40<50$ & 48 & 11.4 \\
\hline$\geq 50$ & 6 & 1.4 \\
\hline Mean \pm SD & \multicolumn{2}{|c|}{$34.1 \pm 7.1$} \\
\hline \multicolumn{3}{|l|}{ Mother Educational level } \\
\hline Illiterate & 14 & 3.3 \\
\hline Basic education & 172 & 40.8 \\
\hline diploma & 90 & 21.3 \\
\hline Institute & 55 & 13.0 \\
\hline University & 91 & 21.6 \\
\hline \multicolumn{3}{|l|}{ Mother Occupation } \\
\hline Work & 140 & 33.2 \\
\hline Not work & 282 & 66.8 \\
\hline \multicolumn{3}{|l|}{ Social status } \\
\hline Living together & 266 & 63.0 \\
\hline Divorce & 87 & 20.6 \\
\hline One of the dead & 69 & 16.4 \\
\hline \multicolumn{3}{|l|}{ Residence } \\
\hline Rural & 6 & 1.4 \\
\hline Urban & 416 & 98.6 \\
\hline \multicolumn{3}{|l|}{ Family income } \\
\hline Enough & 392 & 92.9 \\
\hline Not enough & 30 & 7.1 \\
\hline
\end{tabular}




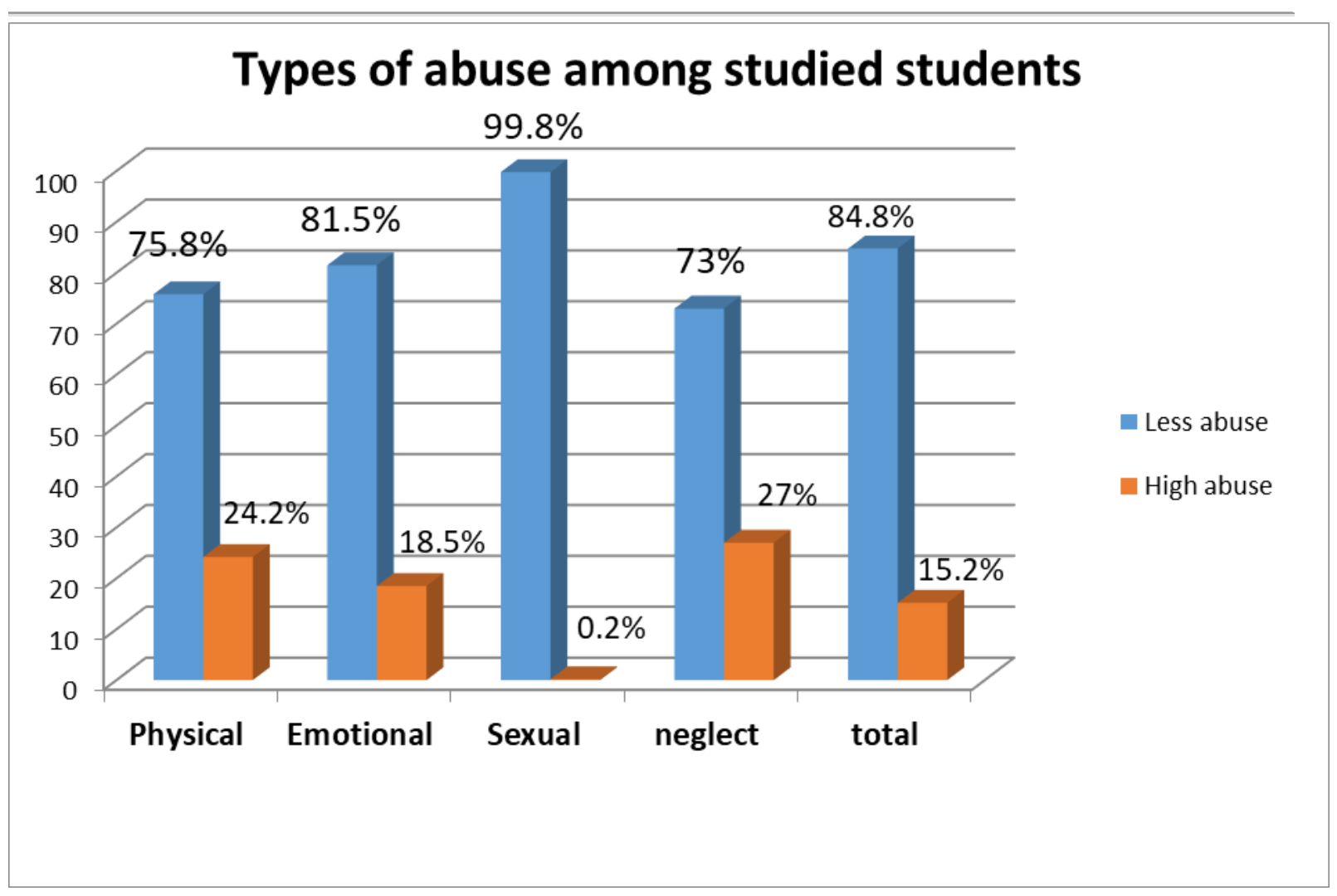

Figure 1: Studied school-age children according to types of abuse $(n=422)$

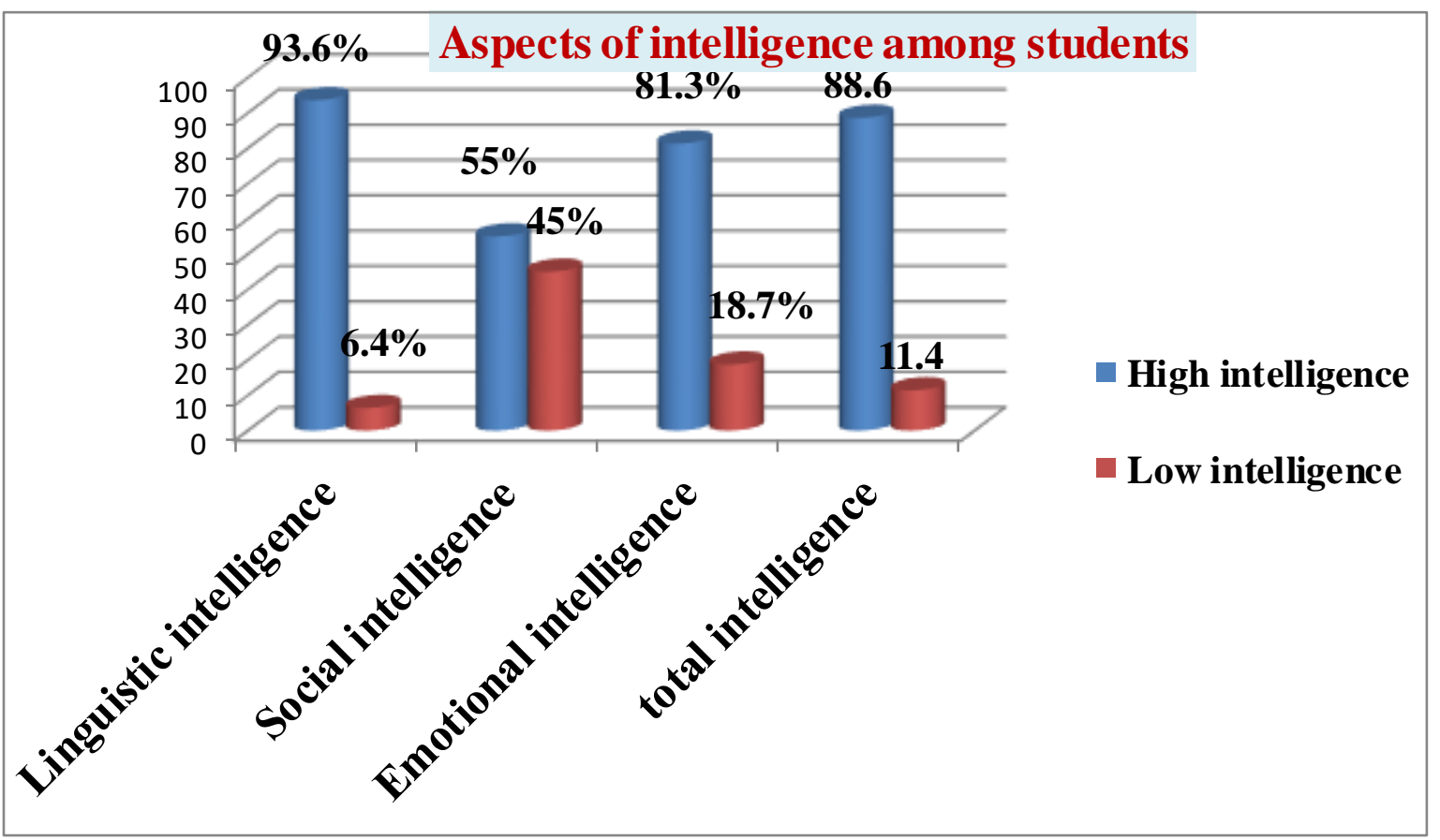

Figure 2: distribution of the studied students according to aspects of intelligence $(n=422)$ 
Table 3: Relation between child characteristics and total physical abuse among studied students:

\begin{tabular}{|c|c|c|c|c|c|c|}
\hline \multirow{3}{*}{$\begin{array}{l}\text { Child } \\
\text { characteristics }\end{array}$} & \multicolumn{4}{|c|}{ Total physical abuse } & \multirow{3}{*}{$\mathbf{X}^{2}$} & \multirow{3}{*}{ P-value } \\
\hline & \multicolumn{2}{|c|}{ Less } & \multicolumn{2}{|c|}{ High } & & \\
\hline & $\mathbf{N}$ & $\%$ & $\mathbf{n}$ & $\%$ & & \\
\hline Age / years & & & & & & \\
\hline $9<10$ & 94 & 76.4 & 29 & 23.6 & 13.01 & $.001 *$ \\
\hline $10<11$ & 111 & 86.0 & 18 & 14.0 & & \\
\hline $11-12$ & 115 & 68.0 & 54 & 32.0 & & \\
\hline Gender & & & & & & \\
\hline Boys & 167 & 75.6 & 54 & 24.4 & .050 & .457 \\
\hline Girls & 153 & 76.5 & 47 & 23.5 & & \\
\hline Grade & & & & & & \\
\hline Fourth & 102 & 78.5 & 28 & 21.5 & & \\
\hline Fifth & 114 & 74.0 & 40 & 26.0 & .762 & .683 \\
\hline Sixth & 104 & 75.9 & 33 & 24.1 & & \\
\hline
\end{tabular}

$X^{2}$-Chi-square test

* significant level at $\mathbf{p}<0.01$

Table 4: Relation between child characteristics and aspects of intelligence among studied students:

\begin{tabular}{|c|c|c|c|c|c|c|c|c|c|c|c|c|c|c|}
\hline \multirow{3}{*}{$\begin{array}{c}\text { Child } \\
\text { characteristi } \\
\text { cs } \\
\end{array}$} & \multicolumn{4}{|c|}{$\begin{array}{c}\text { Linguistic } \\
\text { intelligence }\end{array}$} & \multicolumn{4}{|c|}{ Social intelligence } & \multicolumn{4}{|c|}{ Emotional intelligence } & \multirow{3}{*}{$\mathbf{X}^{2}$} & \multirow{3}{*}{ P-value } \\
\hline & \multicolumn{2}{|c|}{ Low } & \multicolumn{2}{|c|}{ High } & \multicolumn{2}{|c|}{ Low } & \multicolumn{2}{|c|}{ High } & \multicolumn{2}{|c|}{ Low } & \multicolumn{2}{|c|}{ High } & & \\
\hline & $\mathbf{n}$ & $\%$ & $\mathbf{n}$ & $\%$ & $\mathbf{n}$ & $\%$ & $\mathbf{n}$ & $\%$ & $\mathbf{n}$ & $\%$ & $\mathbf{n}$ & $\%$ & & \\
\hline $\begin{array}{l}\text { Age / years } \\
9<10\end{array}$ & 8 & 6.5 & 11 & 93.5 & 51 & 41.5 & 72 & 58.5 & 23 & 18.7 & 100 & 81.3 & .743 & .690 \\
\hline $10<11$ & 10 & 7.8 & $\begin{array}{c}11 \\
9\end{array}$ & 92.2 & 68 & 52.7 & 61 & 47.3 & 31 & 24.0 & 98 & 76.0 & 4.44 & .109 \\
\hline $11-12$ & 9 & 5.3 & $\begin{array}{c}16 \\
1\end{array}$ & 94.7 & 71 & 41.8 & 99 & 58.2 & 25 & 14.7 & 145 & 85.3 & 4.19 & .123 \\
\hline \multicolumn{15}{|l|}{ Gender } \\
\hline Boys & 21 & 9.5 & 20 & 90.5 & 91 & 41.2 & 13 & 58.8 & 37 & 16.7 & 184 & 83.3 & $\begin{array}{l}7.46 \\
2.77\end{array}$ & $\begin{array}{l}.000 * \\
.050 *\end{array}$ \\
\hline Girls & 6 & 3.0 & $\begin{array}{c}19 \\
5\end{array}$ & 97.0 & 99 & 49.3 & $\begin{array}{c}10 \\
2\end{array}$ & 50.7 & 42 & 20.9 & 159 & 79.1 & 1.19 & .257 \\
\hline $\begin{array}{l}\text { Grade } \\
\text { Fourth }\end{array}$ & 12 & 9.2 & 11 & 90.8 & 62 & 47.7 & 68 & 52.3 & 39 & 30.0 & 91 & 70.0 & 4.46 & .091 \\
\hline Fifth & 5 & 3.2 & 14 & 96.8 & 69 & 44.8 & 85 & 55.2 & 23 & 14.9 & 131 & 85.1 & .664 & .717 \\
\hline Sixth & 10 & 7.2 & $\begin{array}{c}12 \\
8\end{array}$ & 92.8 & 59 & 42.8 & 79 & 57.2 & 17 & 12.3 & 121 & 87.7 & 16.03 & $.000 *$ \\
\hline
\end{tabular}


Table 5: Correlation between types of child abuse and aspects of intelligence among studied students:

\begin{tabular}{|l|c|c|c|c|c|c|}
\hline \multirow{2}{*}{ Types of maltreatment } & \multicolumn{2}{|c|}{$\begin{array}{c}\text { Linguistic } \\
\text { intelligence }\end{array}$} & \multicolumn{2}{c|}{ Social intelligence } & \multicolumn{2}{c|}{$\begin{array}{c}\text { Emotional } \\
\text { intelligence }\end{array}$} \\
\cline { 2 - 7 } & $\mathbf{r}$ & $\begin{array}{c}\text { p- } \\
\text { value }\end{array}$ & $\mathbf{r}$ & $\begin{array}{c}\text { p- } \\
\text { value }\end{array}$ & $\mathbf{r}$ & p- value \\
\hline Physical abuse & -.056 & .249 & .052 & .286 & -.025 & .616 \\
& & & & & & \\
\hline Emotional abuse & -.025 & .613 & -.075 & .124 & -.041 & .404 \\
& & & & & & \\
\hline Sexual abuse & -.013 & .794 & .054 & .270 & -.023 & .632 \\
& & & & & & .368 \\
\hline Neglect & $-.148^{* *}$ & .002 & $-.194^{* *}$ & .000 & $-.044-$ & \\
\hline
\end{tabular}

r-Pearson correlation

*. Correlation is significant at the 0.05 level

**. Correlation is significant at the 0.01 level

Table 6: correlation between child total intelligence and total maltreatment among studied students:

\begin{tabular}{|l|c|c|}
\hline \multirow{2}{*}{ Item } & \multicolumn{2}{|c|}{ Total child maltreatment } \\
\cline { 2 - 3 } & $\mathbf{r}$ & $\mathbf{p}$ - value \\
\hline Total intelligence & & .027 \\
\hline r-Pearson correlation & $-.585^{*}$ & \\
\hline
\end{tabular}

\section{DISCUSSION:}

Child maltreatment leads to several long-term consequences in children, adolescents as well as adults. It consists of physical health problems, social and emotional difficulties that affect cognition in relation to poor academic performance and classroom functioning (Dahake, Kale, Dadpe, Kendre, \&Shep, et al., 2018). Child maltreatment has the potential effects to alter a child's neuro-developmental trajectory and substantially increase the risk of later psychiatric disorders, as well as, deleterious impact neurocognitive functioning throughout the lifespan. Child maltreatment has been linked to multiple domains 
of neurocognitive impairment, including language, intelligence, executive functioning, and motor skills (Teicher, Samson, Anderson \&Ohashi, 2016).

The results generally indicate that more than a majority of studied students were less abused, these results might be explained that society becomes more aware of the various forms of child abuse. One-fifth of the studied student were neglect, these results may be attributed to the fact that their parent was had low educational levels. Also, studied students report that their parents commonly refuse my personal demands. As well as, a study with Stoltenborgh, Bakermans-Kranenburg, \&Ijzendoorn (2014), who found that neglect ranged from $6.5 \%$ to $40.0 \%$. Also, a study with Mohammadi, Zarafshan\&Khaleghi (2014), who found that the prevalence of neglect was $57 \%$. More than one-quarter of the studied student in the current study was exposed to physical abuse. This might be explained that the use of physical abuse for discipline and education. Thus the variable rate of physical abuse was reported in different studies $23.3 \%$ by Derakhshanpour, Shahini, Hajebi, Vakili, \&Yazdi, (2017), and 40\% in Zambia, 59\% in Kenya by Mbagaya, Oburu, \&Bakermans-Kranenburg (2013).

Less than one-fifth of studied students in the current study suffered from emotional abuse. This might be because their studied students report that they were commonly forced into things he does not like. Also, increase social stressor. Also, a study by Mahram, Hosseinkhani, Nedjat,\&Aflatouni (2013), who the prevalence of emotional abuse in both genders differs from $17.9 \%$ - 91.1\%, respectively. While, a study by Finkelhor, Vanderminden, Turner, Hamby, \& Shattuck (2014), the prevalence of emotional abuse was 10.3\%.Less than one-fifth of the studied student in the current study were exposed to sexual abuse, these results may be attributed to the fact that a low percentage of studied students were commonly making urination in front of people, these characteristics are not compatible with Egyptian society and its morals. These results agree with Tsuboi, Yoshida, Kojo, Nakamura,\& Kitamura et.al (2013), who found that sexual abuse was $0.6 \%$. Moreover, a study with Saad, Hashish, Abdel-Karim,\& Mohammed (2016), found that sexual abuse about 28.3 in school-age children

The results of the current study indicated more than a majority of studied students were high intelligence, these results may be due to the training of their parents on language skills and their integration in social life to help express their feelings. The majority of studied students had linguistic intelligence in the current study. These results may be attributed to the fact that a high percentage of mothers did not work as they have time to 
improve their children's language skills. Also, Kurt $\underline{(2020)}$, reported that Jean Piaget's theory of cognitive development suggests that children during the school-age period, conceptual abilities become increasingly flexible, during the concrete operational period, they acquire the ability to perform cognitive operations and apply these new skills when thinking about objects, situations, and events. In the same line, Al-Wadi, (2012), found that $77 \%$ - $97.7 \%$ of school-age children have linguistic intelligence. While, a study with Kartiah, AsfahRahman, Qashas Rahman,\&Jabu (2014), found that linguistic intelligence was $56 \%$.

More than half of the studied students had high social intelligence. This might be explained by the fact the highest percentage of parents living together, as this encourages the strengthening of family and social relations in Egyptian society. These findings are supported by Kennedy-Murray (2016), who found that social intelligence was 53\%. Also, a study with Maftoon, \&Sarem (2012), found that social intelligence was 98.8\%.In the current study, the majority of studied students had emotional intelligence. These results may be attributed to the fact that a high percentage of studied students age between (11-12 years). Emotional intelligence with maturation is shown through an increase with age. Similarly, Singh, Makharia, Sharma, Agrawal, \&Varma et al.(2017), found that prevalence rates of emotional intelligence ranged from $88.3 \%-90.2 \%$.

In the present study, a statistically significant relationship between total physical abuse and age, increase exposure to physical abuse with increasing age of the studied student. The present findings are supported by Saad, Hashish, Abdel-Karim, \&Mohammed (2016), who found statistically significant relationships between the type of abuse and the child's age. On the other hand, study finding by Bengwasan (2018), who reported that significant differences with age, and type of abuse

In present, study a statistically significant relationship between linguistic intelligence and gender of the child, girls tend to show linguistic intelligence significantly higher than boys. Similarly, the study by Al-Faoury\&Smadi, (2015), who found that boys favored logical intelligence while girls favored linguistic intelligence. On the other hand, a study by Punia\&Jyoti (2016), who found that no gender discrimination was found on linguistic intelligence.

In the current study, the statistically significant relationship between social intelligence and gender of the child, boys tend to show social intelligence significantly higher than girls, this may be related to boys wants to peer, that better than girls. However, 
the study by Saxena\& Jain, (2013), who found that gender analysis indicates that girls student's pass more social intelligence than boys students

The statistically significant relationship between emotional intelligence and the grade of the child, children in sixth grade tend to show emotional intelligence significantly higher than fourth and fifth grade ( $\mathrm{P}=$ less than .000). This may be related to that the child begins to be emotionally mature than the previous as they grow in age occur. The present study findings supported by Nayak (2014), who found that a significant correlation between school-age and emotional intelligence.

The present study showed a negative correlation between neglect and linguistic, social intelligence $(\mathrm{P}=.002)$, in this regard (Spratt, Friedenberg, Swenson, Larosa,\& De Bellis, et al, 2012), reported that children with high exposure to neglect that contact poor social relationship and language problem, slow language development plays a role in behavioral difficulties across the life span, Children with a history of neglect are at risk for impaired language development. The present results are similar to Sylvestre, Bussieres, \& Bouchard, (2016), who found a significant inverse association between neglect and language. However, a study by Mcdonald, Milne, Knight, \& Webster (2013), who found a significant positive relationship between exposure to abuse and/or neglect in the early years of life and the development of a child, especially with language, social development.

In general, the results of the present study revealed that there statistically significant negative correlation between total child maltreatment and total intelligence among studied students, the children who are highly exposed to maltreatment have low intelligence. These results are supported by Coohey, Renner, Hua, Zhang, \& Whitney (2011), who found a relationship between the type of maltreatment and lower intelligence. Also, De Bellis\&Zisk (2014), demonstrated that child maltreatment could be linked to the global cognitive deficit, including impaired intelligence. Furthermore, a study by Irigaray, Pacheco, Grassi-Oliveira, Fonseca, \& De Carvalho, et al., (2013), who found that maltreatment during childhood had deleterious effects on attention and cognitive functioning

\section{CONCLUSION:}

The most common maltreatment among the studied students were neglect, $27 \%$, and physical abuse, $24.2 \%$, followed by emotional abuse, $18.5 \%$, and only, $0.2 \%$, were exposed to sexual abuse. The majority of studied students had linguistic and emotional intelligence. 
There was a negative correlation between child abuse and the selected aspects of intelligence (linguistic, social, and emotional).

\section{RECOMMENDATIONS:}

In the light of the current study results, the following recommendations are recommended:

1. Periodic assessment of school-age children about forms of abuse and aspects of intelligence

2. Conduct a training program for the parent about the seriousness of the abuse and its effects on the level of intelligence

3. A comprehensive guidance program to support school-age psychologically and socially as a result of their abuse

\section{REFERENCE}

Abatha, A. (2005). The scale of abuse and neglect for ordinary and non - ordinary children The Anglo - Egyptian Library Cairo.Retrived from https://www.angloegyptian.com/ar/book.phpid=13042 At 20/7/2018

Al-Faoury, H. O.,Smadi, M. O. (2015). The Effect of an integrative skills program on developing Jordanian university students select multiple intelligences. Theory and Practice in Language Studies, 5(1):

Al-Qatros, N. (2008). Relationship between parenting styles and intelligence and school achievement for children in the late childhood period, The Scale of Social And Emotional Intelligence, Islamic University Of Gaza. Retrieved from library.iugaza.edu.ps/thesis/81483.pdf At 22/7/2018

Al-Wadi, N. I. (2012). Teachers' perceptions toward enhancing learning through multiple intelligences theory in elementary school: A mixed-methods study (Doctoral dissertation).

Bengwasan, P. D. (2018). The intellectual profile of abused and neglected children in the Philippines: An analysis of SB5 IQ scores of sexually abused, physically abused, and neglected children. Child abuse \& neglect, 81, 389-395.

Charan., J and Biswas T. (2013). How to calculate sample size for different study designs in medical research. Indian Journal of Psychological Medicine, 35(2): 121-126. 
Coohey, C., Renner, L. M., Hua, L., Zhang, Y. J., \& Whitney, S. D. (2011). Academic achievement despite child maltreatment: A longitudinal study. Child Abuse \& Neglect, 35(9), 688-699

Dahake, P. T., Kale, Y., Dadpe, M., Kendre, S., Shep, S., \&Dhore, S. (2018). Impact of child abuse \& neglect on children: A review article. MIDSR Journal of Dental Research, $1(1)$.

Davis, A. S., Moss, L. E., Nogin, M. M., \& Webb, N. E. (2015).Neuropsychology of child maltreatment and implications for school psychologists. Psychology in the Schools, 52(1), 77-91.

De Bellis MD, Zisk AAB (2014) The biological effects of childhood trauma. Child Adolesc Psychiatr Clin N Am 23(2):185-222

Derakhshanpour, F., Shahini, N., Hajebi, A., Vakili, M. A., \&Yazdi, A. S. H. (2017). Demographic characteristics and risk actors of children and parents in child abuse subtypes: Findings from a psychosocial support department. Journal of Fundamentals of Mental Health, 19(6), 481-490.

Finkelhor, D., Vanderminden, J., Turner, H., Hamby, S., \& Shattuck, A. (2014). Upset among youth in response to questions about exposure to violence, sexual assault, and family maltreatment. Child abuse \& neglect, 38(2), 217-223

Ghanem, H. (2011). Linguistic intelligence among the students of middle school.The scale of Linguistic Intelligence.Journal of Educational and Psychological Research, Baghdad University. (31) 143-170

Hughes, M., \&Cossar, J. (2016). The relationship between maternal childhood emotional abuse/neglect and parenting outcomes: A systematic review. Child Abuse Review, 25(1), 31-45.

IrigarayI TQ, PachecoII JB, Grassi-OliveiraI R, FonsecaI RP, De Carvalho JC, KristensenI CH (2013) Child maltreatment and later cognitive functioning: a systematic review. Psicol Reflex Crít 26(2):376-387 
Kartiah, S. R., Rahman, M. A., Rahman, A. Q., \&Jabu, B. (2014).The Portrayal of multiple intelligence theory in English teaching strategy for Indonesian secondary school. Journal of Language Teaching \& Research, 5(5).

Keane, M., Guest, A., \&Padbury, J. (2013). A balancing act: A family perspective to sibling sexual abuse. Child abuse review, 22(4), 246-254.

Kennedy-Murray, L. N. (2016). Teachers' perceptions and practices of multiple intelligences theory in middle schools At 27/5/2019

Kurt, S. "Jean Piaget and His Theory \& Stages of cognitive development," in $\begin{array}{llllll}\text { educational } & \text { technology, } & \text { August } & \text { 8 } & \text { Retrieved } & \text { from }\end{array}$ https://educationaltechnology.net/jean-piaget-and-his-theory-stages-of-cognitivedevelopment/At 21/11/2020

Maftoon, P., \&Sarem, S. (2012). The realization of Gardner's multiple intelligences (MI) theory in second language acquisition (SLA). Journal of Language Teaching \&Research, 3(6), 1233-1241. doi:10.4304/jttr.3.6.1233-124

Mahram M, Hosseinkhani Z, Nedjat S, Aflatouni A. Epidemiologic evaluation of child abuse and neglect in school-aged children of qazvin province, Iran. Iran J Pediatr 2013; 23: 159-164

Mansour, N. (2008). Child abuse in relation to self- esteem a psychometric- clinical Study, the scale of sexual abuse. Zagazig University.Faculty of Education. Retrieved from https://www.ahlalhdeeth.com/vb/attachment.php.attachmentid=103079\&d At 24/7/2018

Mbagaya C, Oburu P, Bakermans-Kranenburg MJ. Child physical abuse and neglect in Kenya, Zambia, and the Netherlands: a cross-cultural comparison of prevalence, psychopathological sequelae and mediation by PTSS. Int J Psychol 2013; 48: 95-107

McDonald, J. L., Milne, S., Knight, J., \& Webster, V. (2013). Developmental and behavioural characteristics of children enrolled in a child protection pre-school. Journal of Paediatrics and Child Health, 49, E142-E146. 
Mohammadi, M. R., Zarafshan, H., \&Khaleghi, A. (2014). Child Abuse in Iran: a systematic review and meta-analysis. Iranian journal of psychiatry, 9(3), 118.

Nayak, M. (2014). Impact of culture linked gender and age on emotional intelligence of higher secondary school adolescents. International Journal of Advancements in Research and Technology, 3(9), 64-79.

Punia, M. V., \&Jyoti, J.(2016) Effect Of Gender On Underlying Factors Of Multiple Intelligence Among School Going Children At 11/6/2019

Saad, S., Hashish, R., Abdel-Karim, R., \& Mohammed, G. (2016).Emotional, physical, and sexual abuse and its psychological impact in children.International journal of contemporary pediatrics, 3(3), 760-767.

Saxena, S., \& Jain, R. K. (2013).Social intelligence of undergraduate students in relation to their gender and subject stream. Journal of Research \& Method in Education, $1(1), 1-4$.

Singh, Y., Makharia, A., Sharma, A., Agrawal, K., Varma, G., \&Yadav, T. (2017).A study on different forms of intelligence in Indian school-going children.Industrial psychiatry journal, 26(1), 71.

Singh.,S.(2017). Human intelligency in sports 4(5): 22-24 International Journal of Physical Education, Sports and Health 2017; 4(5): 22-24

Spratt, E. G., Friedenberg, S. L., Swenson, C. C., LaRosa, A., De Bellis, M. D., Macias, M. M., .. \& Brady, K. T. (2012). The effects of early neglect on cognitive, language, and behavioral functioning in childhood. Psychology (Irvine, Calif.), 3(2), 175

Stoltenborgh, M., Bakermans-Kranenburg, M. J., Alink, L. R., \&IJzendoorn, M. H. (2014). The prevalence of child maltreatment across the globe: Review of a series of meta analyses. Child Abuse Review, 24(1), 37-50. https://doi.org/10.1002/car.2353.

Sylvestre, A., Bussières, È. L., \& Bouchard, C. (2016). Language problems among abused and neglected children: A meta-analytic review. Child maltreatment, 21(1), 47-58. 
Teicher, M. H., Samson, J. A., Anderson, C. M., \&Ohashi, K. (2016).The effects of childhood maltreatment on brain structure, function, and connectivity. Nature reviews neuroscience, 17(10), 652.

Tsuboi S, Yoshida H, Ae R, Kojo T, Nakamura Y, Kitamura K.(2013) Prevalence and demographic distribution of adult survivors of child abuse in Japan. Asia Pac J Public Health .

Van der Put, C. E., Assink, M., Gubbels, J., \& van Solinge, N. F. B. (2018).Identifying effective components of child maltreatment interventions: A metaanalysis. Clinical child and family psychology review, 21(2), 171-202.

Witt, A., Brown, R. C., Plener, P. L., Brähler, E., \&Fegert, J. M. (2017). Child maltreatment in Germany: prevalence rates in the general population. Child and adolescent psychiatry and mental health, 11(1), 47.

World Health Organization (2017).Child Maltreatment. Retrieved from World Health Organization (WHO) website: http://www.who.int/violence_injury_prevention/violence/child/Child_maltreatment_infogra phic_EN.pdf. ua=1At 9/7/2018 


\section{تاثير سوء المعاملة على جوانب الذكاء المختارة بين الاطفال في سن المدرسة

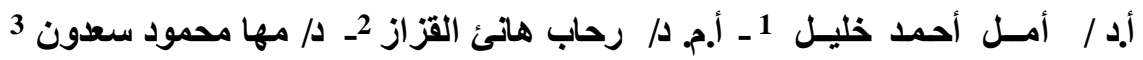 \\ ايمان محمد الضيفي عبدالغتي احمد 4}

أستـاذ تمريض الأطفـال1 ـ أستـاذ مساعد تمريض الاطفال2 ـ مدرس تمـريض الأطفـال3 ــ معيدة بقسم تمريض

الاطفال4 - كلية التمريض، جامعـة بورسعيد

\section{الخلاصة}

سوء معاملة الأطفال له نأثيرعلي الذكاء اللغوي والاجتماعي والعاطفي الذي بدوره يتسبب في انخفاض مسنوى التحصيل الدراسي. هدف الدراسة: تحديد تأثير سوء المعاملة على جوانب الذكاء المختارة (اللغويـ الاجتماعيـ النفسي) بين الأطفال في سن المدرسة. طرق وأدوات البحث: تم استخدام البحث الوصفي الارتباطي لإجراء الدراسة الحالية عن طريق استخدام العينة العشوائية العنقودية في 12 مدرسة ابتدائية تمثل القطاعات الستة بمدينة بورسعيد. إجمالي العينة 422 طالبًا نتراوح أعمار هم بين 9-12عامًا. أدوات جمع البياتات: استمارة مقابلة للبيانات الاجتماعية

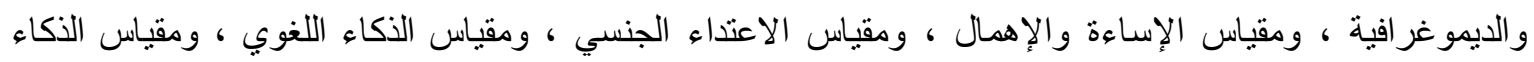

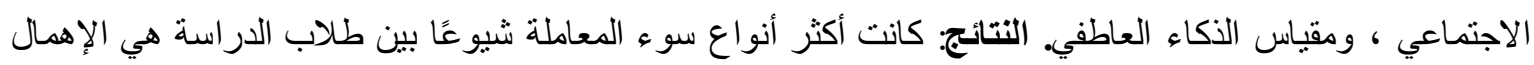

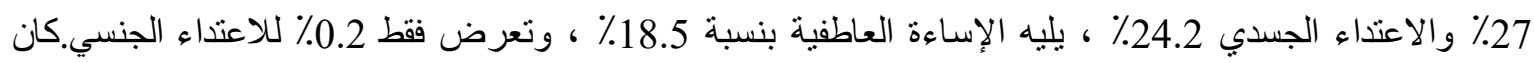
غالبية طلاب الدراسة لديهم ذكاء لغوي وعاطفي مرتفع .الخلاصة: هناك ارتباط عكسي بين إساءة معاملة الأطفال وجو انب الذكاء المختارة( اللغوي -الاجتماعي _النفسي). التوصيات:إجر اء برنامج تدريبي للأبوين حول خطورة الإساءة و آثار ها على مستوى الذكاء الكلمات المرشدة: سوء معاملة الأطفال، الذكاء، الأطفال في سن المدرسة 